\title{
An updated diagnosis of the rare Amphisbaena slateri Boulenger, 1907, based on additional specimens (Squamata, Amphisbaenia, Amphisbaenidae)
}

\author{
Henrique C. Costa ${ }^{1}$, Luke J. Welton ${ }^{2}$, Jakob Hallermann ${ }^{3}$ \\ 1 Programa de Pós-Graduação em Zoologia, Universidade Federal de Minas Gerais. Avenida Antônio Carlos 6627, Pampulha, Belo Horizonte, \\ 31270-90, Minas Gerais, Brazil \\ 2 Division of Herpetology, University of Kansas Biodiversity Institute, 1345 Jayhawk Blvd., Lawrence, KS 66045, USA \\ 3 Universität Hamburg, Centrum für Naturkunde, Martin-Luther-King-Platz 3, 20146 Hamburg, Germany
}

http://zoobank.org/1036F066-E737-4ACF-95E9-00E78425169B

Corresponding author: Henrique C. Costa (ccostah@gmail.com)

Received 29 June 2018

Accepted 24 August 2018

Published 19 September 2018

Academic editor:

Andreas Schmidt-Rhaesa

\section{Key Words}

\section{Bolivia}

Carl Gans

Museum

Peru

Reptile

Taxonomy

\begin{abstract}
Amphisbaena slateri is a rare species of worm lizard from Peru and Bolivia, known only from three specimens. We found two additional specimens of this taxon, housed at the herpetological collections of the Zoological Museum (Cenak), Universität Hamburg, and the University of Kansas Biodiversity Institute, updating its known geographic distribution and morphological variation. We also discovered an unpublished manuscript by late Carl Gans reporting the finding of the Hamburg specimen, which we reproduce here with the permission of his family. Amphisbaena slateri can be identified by a combination of characters including counts of annuli, segments, and pores, the shape of head scales and color pattern. Basic morphological data is given for all species of Amphisbaenia known for Bolivia and Peru to aid in the identification of specimens from those countries.
\end{abstract}

\section{Introduction}

Amphisbaena slateri was described more than a century ago based on a single specimen from southern Peru, deposited in the British Museum, London, UK (BM) (Boulenger 1907). Six decades later, the species was redescribed after the discovery of two specimens from Bolivia, housed in the Zoological Museum, Universität Hamburg (ZMH), and the Museum für Naturkunde, Berlin, Germany (ZMB) (Gans 1967). Since then, no relevant information on $A$. slateri has been published.

While searching for data of the three known specimens of Amphisbaena slateri, the senior author was informed about the existence of another specimen housed at the $\mathrm{ZMH}$, and a specimen at the University of Kansas Biodiversity Institute (KUH). The Hamburg specimen (ZMH R01282) was first identified as Amphisbaena sp. in the collection catalog. In 1980, the prominent herpetologist and amphisbaenian expert Carl Gans (1923-2009) re-identified it as A. slateri. Gans planned to disclose his finding and typed a short note, which was not published (see Discussion). Later, ZMH R01282 was cited as $A$. slateri in a checklist of amphibians and reptiles of the lower Llullapichis River (Schlüter et al. 2004) without further information. The Kansas specimen (KUH 135171) was identified as $A$. slateri in the collection database, but apparently, no one had noticed its importance to the knowledge on the taxonomy and distribution of the species, and it was never cited in the published literature. 
Knowledge on the systematics of South American amphisbaenians has rapidly advanced in recent years, with the description of many new species and the proposals of phylogenetic relationships (Mott and Vieites 2009, Colli et al. 2016). These advances, however, are mostly related to Brazilian species, and little has been published in this decade on the taxonomy of species from other South American countries (Perez et al. 2012, Ribeiro et al. 2015, Montero 2016, Costa et al. 2018). Given the apparent rarity of $A$. slateri and the scarce information on its morphology, it is important to unveil the existence of the above-cited specimens and to provide an updated description for this taxon, comparing it with other species from Bolivia and Peru.

\section{Material and methods}

The two specimens housed in the Zoologisches Museum, Universität Hamburg (ZMH R01282 and R05908) and the specimen housed at the University of Kansas (KUH 135171) were personally examined and photographed by JH and LJW, respectively. Data from the holotype housed in the British Museum, London, UK (BM 1946.8.31.82, former 1907.5.2-RR) and the specimen in the Museum für Naturkunde, Berlin, Germany (ZMB 10888) was based on the species redescription (Gans 1967) and on the examination of photographs. We also searched for information on specimens identified as Amphisbaena slateri in VertNet (http://portal.vertnet.org).

For comparisons with other species we used information from preserved specimens (see appendix in Costa et al. (2018), and Appendix 1) in addition to data from taxonomic studies, especially those on Bolivian and Peruvian taxa (Werner 1901, Gans 1961, 1962a, 1962b, 1963, 1964d, 1966, Gans and Amdur 1966, Gans and Diefenbach 1972, Montero 1996, 2001, Vanzolini 1999, 2002, Ribeiro et al. 2015), although not restricted to them (Gans and Alexander 1962, Gans 1964a, 1966, Perez et al. 2012). We further examined a series of photographs of three paratypes of Amphisbaena pericensis from the Field Museum of Natural History (FMNH 16106, 16107, and 73371). Nomenclature for head scales follows Gans and Alexander (1962). Measurements were taken with a ruler and a caliper to the nearest $1.0 \mathrm{~mm}$ and $0.01 \mathrm{~mm}$, respectively.

Biomes and ecoregions follow Dinerstein et al. (2017). Geographical coordinates were assessed with the aid of Google Earth Pro software and pertinent literature (Evans 1903, Stephens and Traylor 1983, Dirksen and Riva 1999, United States Government 2001). Maps were prepared using QGis 2.14.3 (https://qgis.org/en/site/).

\section{Results}

The specimen ZMH R01282 was collected by Hans-Wilhelm Koepcke in June 1973 at Panguana Private Conser- vation Area (9॰37'S, $\left.74^{\circ} 56^{\prime} \mathrm{W}\right)$, left margin of the Llullapichis (Yuyapichis) River, a tributary of the right margin of the Pachitea River, Departamento de Huánuco, $260 \mathrm{~m}$ elevation. It was found when the collector was digging in a garden inside the forest (Suppl. material 1). Specimen KUH 135171 (field number THF 1796) was collected by Thomas H. Fritts in January 1968 at Misión Coribeni (12 $36^{\circ}$ S, $\left.72^{\circ} 48^{\prime} \mathrm{W}\right)$, Departamento de Cuzco, Peru.

Morphology of ZMH R01282 and KUH 135171 is within the range described for most characters of Amphisbaena slateri, but slightly increases the maximum values of snout-vent length (from 139 to $163 \mathrm{~mm}$ ), number of body annuli (from 206 to 213), and caudal annuli (from 21 to 24) (Table 1). The tail of ZMH R01282 is separate from the body. Regarding color, KUH 135171 has the typical pattern described for $A$. slateri, i.e., uniform dark brown (although without a white tail tip). Comparatively, ZMH R01282 has a uniform light brown color.

Our search on VertNet returned only three results: KUH 135171 and two specimens from 'Peru' housed in the Louisiana State University Museum of Natural Science, Baton Rouge, USA (LSUMZ 27189 and 27190). We received photographs and morphological data of these two specimens provided by the LSUMZ staff (Jackson Roberts, e-mail to HC on 27 March 2018). The specimens are probably juveniles, with only $\sim 50 \mathrm{~mm}$ total length. Based on the available data we confirmed they cannot be assigned to A. slateri or any other Peruvian species further discussions on their identification are outside the scope of the present paper.

\section{Systematics}

\section{Squamata Oppel, 1811}

Amphisbaenia Gray, 1844

Amphisbaenidae Gray, 1825

Amphisbaeninae Gray, 1825

\section{Amphisbaena Linnaeus, 1758}

Amphisbaena slateri Boulenger, 1907: 487.

Heterochresonymy. Amphisbaena darwinii: (Werner 1910) - erroneous identification of ZMH R05908.

Type material. Holotype, BM 1946.8.31.82 (former 1907.5.2-RR), undetermined sex, collected sometime prior to 2 May 1907 by Thomas Slater and presented by him to the British Museum through Prof. G. S. Boulger (Boulenger 1907) (Figure 1).

Type-locality. San Gaban river valley, Provincia de Carabaya, Departamento de Puno, Peru, between 20003000 feet ( $600-900 \mathrm{~m})$ above sea level. Originally cited as "Peru, obtained in the Rio San Gaban Valley, Prov. Carabaya, altitude 2000-3000 feet" (Boulenger 1907).

Definition. Amphisbaena slateri is defined by the following combination of characters: (1) rounded head, not compressed or depressed; (2) length of frontal suture $><$ prefrontal $>$ nasal sutures; (3) four precloacal pores with- 
Table 1. Morphological data of the five known specimens of Amphisbaena slateri.

\begin{tabular}{l|c|c|c|c|c}
\hline \multicolumn{1}{c|}{ Characters / Specimens } & $\begin{array}{c}\text { BM 1946.8.31.82 } \\
\text { (holotype) }\end{array}$ & ZMB 10888 & $\begin{array}{c}\text { ZMH R05908 } \\
\text { (former 3434) }\end{array}$ & ZMH R01282 & KUH 135171 \\
\hline Snout-vent + tail length & $138+\mathrm{x} \mathrm{mm}$ & $139+20 \mathrm{~mm}$ & $112+16 \mathrm{~mm}$ & $148+18 \mathrm{~mm}$ & $163+22 \mathrm{~mm}$ \\
\hline Body annuli & 206 & 176 & 183 & 213 & 202 \\
\hline Lateral annuli & 3 & 3 & 4 & 3 & 3 \\
\hline Caudal annuli & $9+$ (broken) & 21 & 20 & 22 & 24 \\
\hline Autotomic caudal annulus & 9 & 7 & 8 & 9 & 10 \\
\hline Midbody dorsal segments & 10 & 14 & 12 & 10 & 12 \\
\hline Midbody ventral segments & 14 & 16 & 16 & 14 & PF $>\mathrm{F}>\mathrm{N}$ \\
\hline Head shields sutures & $\mathrm{F}>\mathrm{PF}>\mathrm{N}$ & $\mathrm{PF}>\mathrm{N}^{*}$ & $\mathrm{~F}>\mathrm{PF}>\mathrm{N}$ & $\mathrm{F}=\mathrm{PF}>\mathrm{N}$ & 3 \\
\hline Supralabials & 3 & 3 & 3 & 3 & 3 \\
\hline Infralabials & 3 & 3 & 3 & 3 & $2+2$ \\
\hline Postgenials & $2+3$ & 3 & 3 & 0 & 7 \\
\hline Postmalars & 0 & 0 & 0 & 12 & 8 \\
\hline Precloacal scales & 8 & 6 & 11 & 12 & 11 \\
\hline Postcloacal scales & 10 & 11 & & & \\
\hline
\end{tabular}

* ZMB 1088 has only the left frontal.

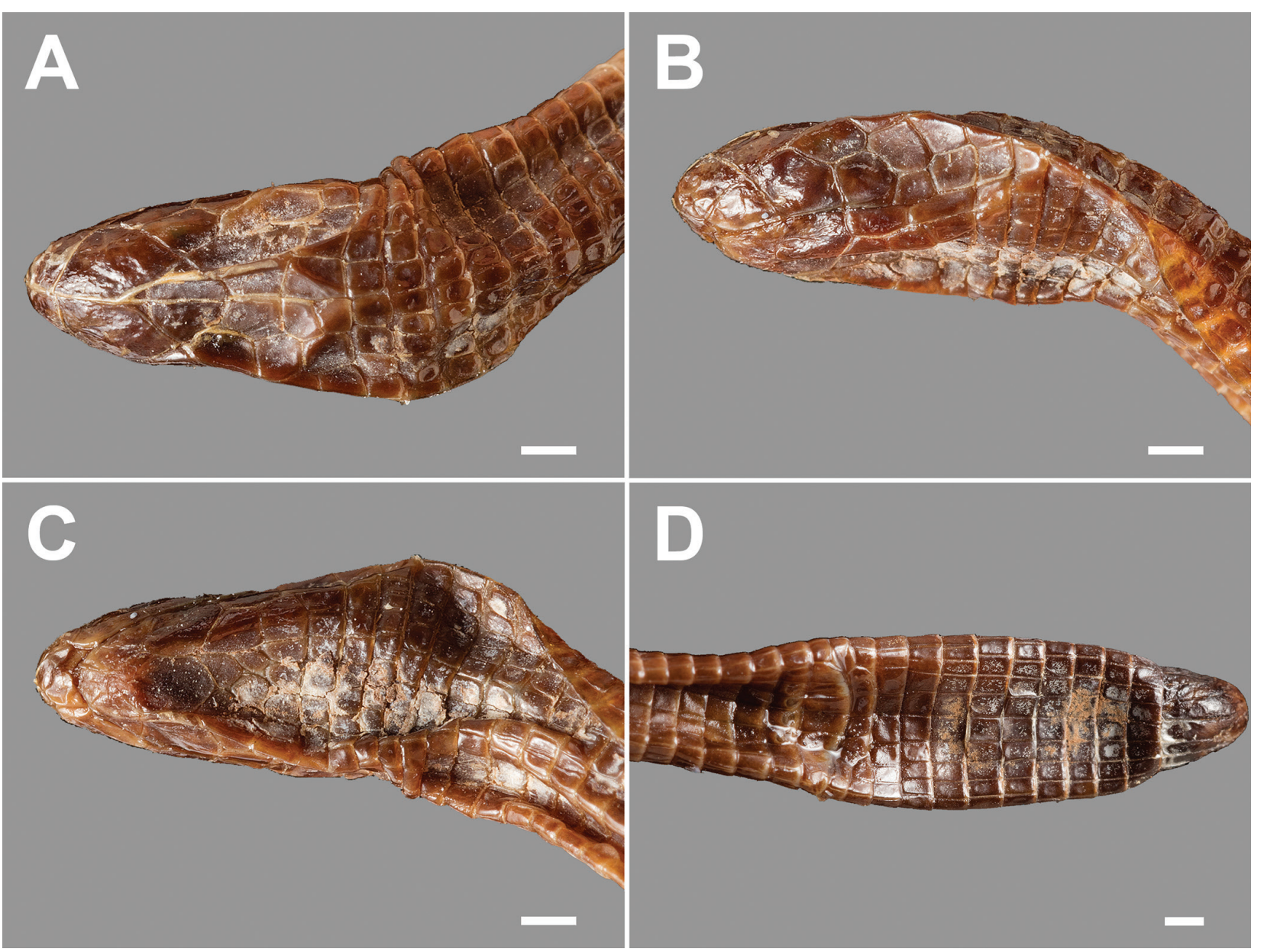

Figure 1. Holotype of Amphisbaena slateri (BM 1946.8.31.82), from the San Gaban river valley, Peru. Note the specimen's poor condition. A) head in dorsal view; B) head in lateral view; C) head in ventral view; D) cloacal region and tail (autotomized) in ventral view. Scale bars: $1 \mathrm{~mm}$. Photos: Natural History Museum, UK.

out a median hiatus; (4) lateral sulcus present, dorsal and ventral sulci absent; (5) 176-213 body annuli; (6) three or four lateral annuli; (7) 20-24 caudal annuli; (8) autotomy constriction on caudal annulus 7-10; (9) tail round in cross-section, with similar width along its length; (10) dorsal surface of tail with non-tuberculate segments; (11) tail tip round, segmented, not compressed; (12) 10-14 dorsal and 14-16 ventral segments on a midbody annulus 


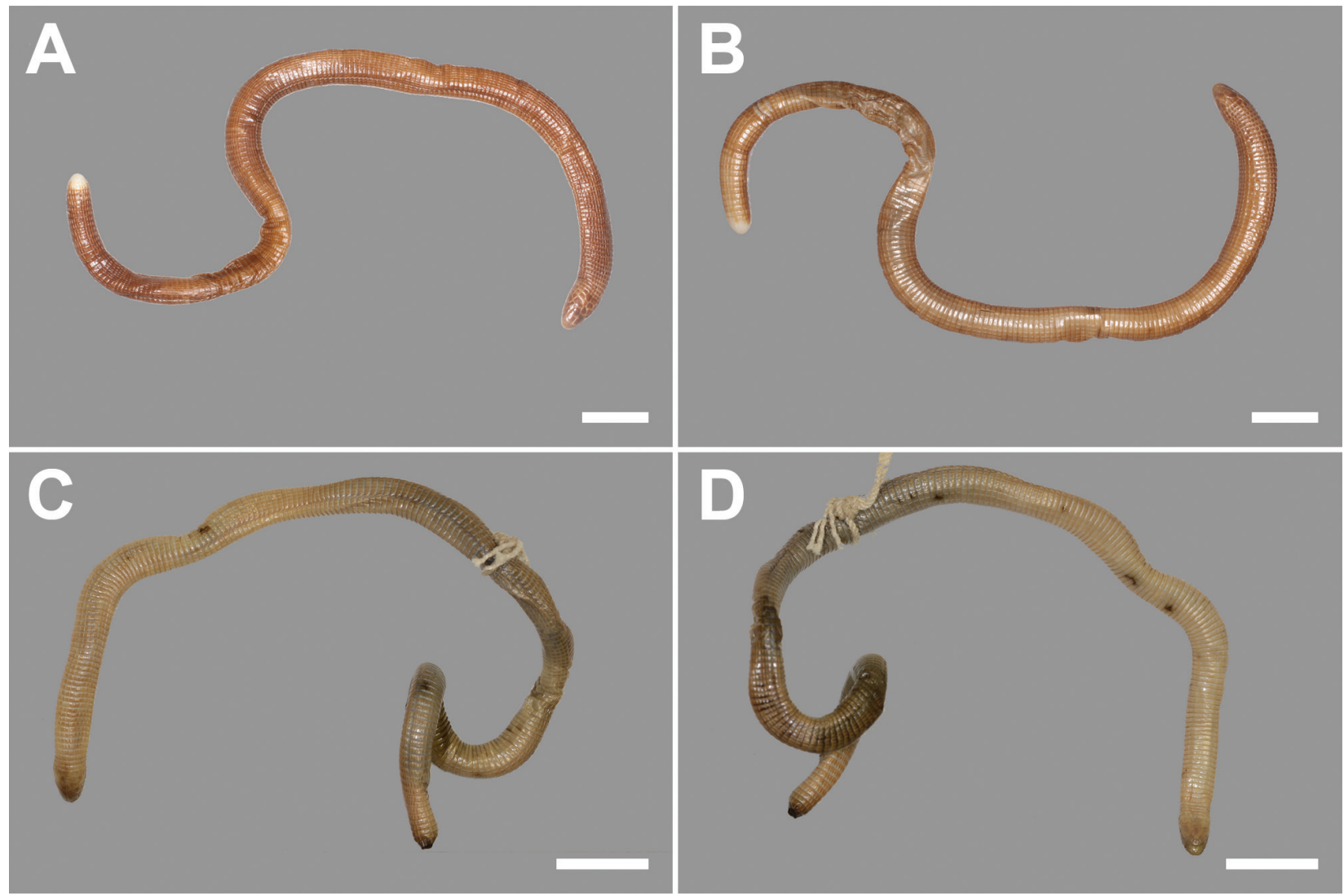

Figure 2. General view of the dorsum and venter of the body of ZMB 10888 (Pelechuco, Bolivia) (A, B) and ZMH R01282 (Panguana Private Conservation Area, Peru) (C, D). Note the difference in color pattern. Tail tip of ZMH R01282 is broken and not shown. Scale bars: 10 mm. Photos: Frank Tillack (A, B) and Jakob Hallermann (C, D).

(24-30 total midbody segments); (13) three supralabials; (14) three infralabials; (15) a pair of enlarged pentagonal parietals; (16) one postocular; (17) one temporal; (18) postmental distinctly longer than mental; (19) one or two rows of postgenials; (20) postmalar row present or absent; (21) dorsum and venter uniformly dark brown or light brown in preservative, with a white or a brown tail tip. Basic morphological data are present in Table 1, and photographs of the five known specimens are shown in Figures 1-4.

Diagnosis. Among the Bolivian and Peruvian amphisbaenians (characters inside parenthesis) the round head distinguishes Amphisbaena slateri from A. kingii Bell, 1833, (keel-headed) and Leposternon microcephalum Wagler, 1824 (shovel-headed). The four precloacal pores distinguish it from A. silvestrii Boulenger, 1902 (two pores) and A. fuliginosa Linnaeus, 1758 (6-10 pores). The presence of 176-213 body annuli distinguishes A. slateri from A. borelli Peracca, 1897 (239-261), A. occidentalis Cope, 1876 (262-275), A. polygrammica Werner, 1900 (270), A. steindachneri Strauch, 1881 (255-266), and A. townsendi Stejneger, 1911 (261-279). By having 10-14 dorsal segments at midbody, A. slateri differs from A. alba (30-42), A. angustifrons Cope, 1861 (20-31), A. bolivica Mertens, 1929 (27-38), A. camura Cope, 1862 (28-42), A. cegei Montero, Sáfadez \& Álvarez, 1997 (17-22), and A. vermicularis Wagler, 1824
(18-26). Amphisbaena slateri differs from A. heterozonata Burmeister, 1861 - sometimes considered a subspecies of $A$. darwinii Duméril \& Bibron, 1839 (Montero 2016) - by the having 20-24 caudal annuli (vs. 13-18), enlarged parietals (vs. rarely enlarged), and a uniform body coloration (vs. dorsum brown, venter cream). Despite a small overlap in midbody dorsal/ventral segment counts between A. slateri (10-14/14-16) and A. heterozonata (14-24/15-28), specimens of the later most commonly have 16/18 segments. Finally, A. slateri differs from $A$. pericensis Noble, 1921 by lacking a compressed tail tip (vs. slightly laterally compressed), by having a postmental longer than the mental (vs. postmental faintly longer than mental) and having a uniform body coloration (vs. dorsum brown, venter cream). A summary of morphological characters useful to identify Peruvian and Bolivian amphisbaenids is present in Table 2.

Expanding comparisons to all Neotropical amphisbaenians, we find an overlap of most morphological character states between $A$. slateri and A. albocingulata Boettger, 1885, A. darwinii Duméril \& Bibron, 1839, $A$. hogei Vanzolini, 1950, A. manni Barbour, 1914, A. mensae Castro-Mello, 2000, A. munoai Klappenbach, 1960, A nigricauda Gans, 1966, A. prunicolor (Cope, 1885), A. schmidti Gans, 1964, and A. talisiae Vanzolini, 1995. The uniform color pattern of $A$. slateri distinguishes it from A. albocingulata, A. darwinii, A. hogei, A. mensae, 


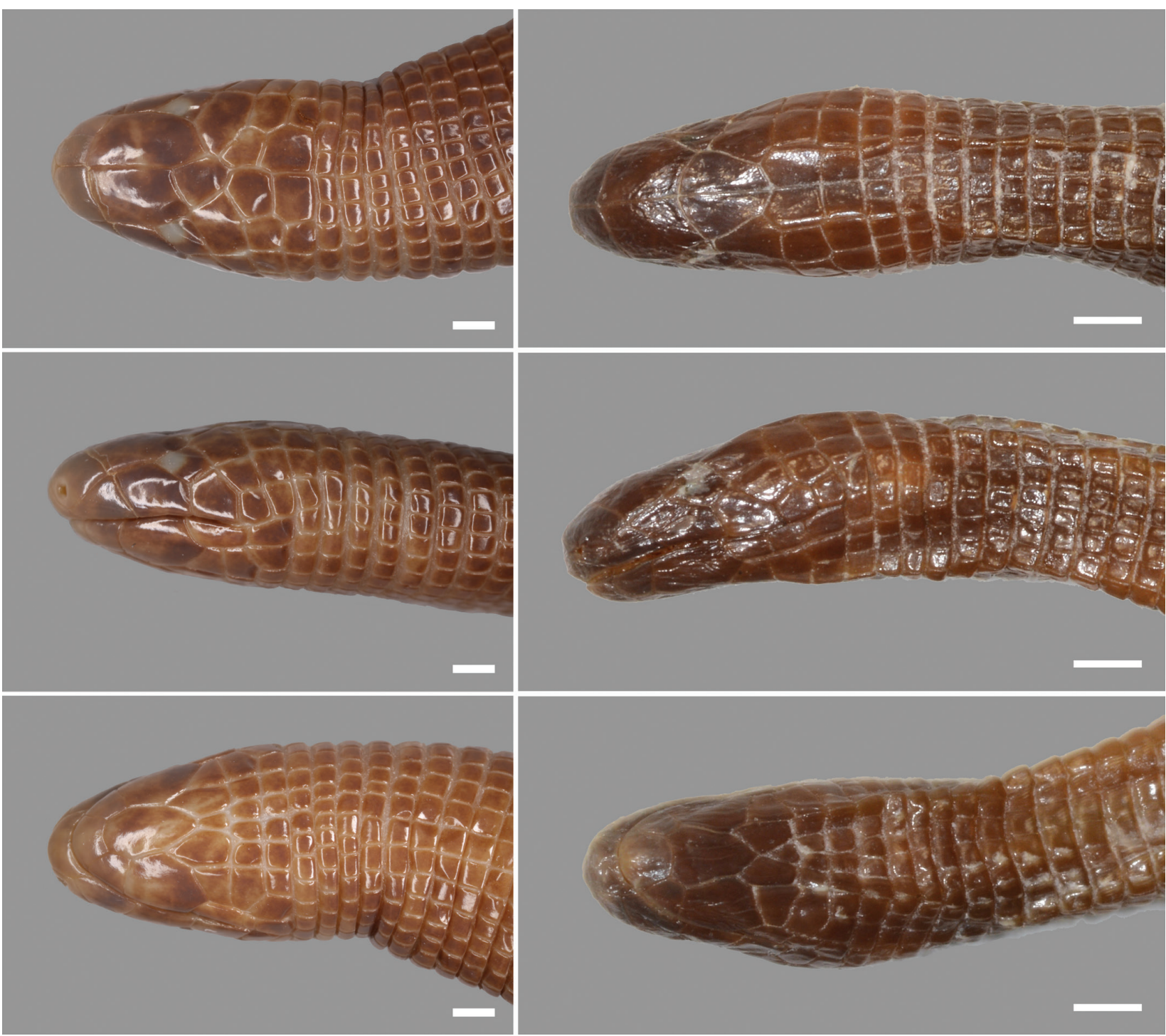

Figure 3. Amphisbaena slateri. Head in dorsal, lateral, and ventral view of ZMB 10888 (left), from Pelechuco, and ZMH R05908 (right), from San Antonio, Bolivia. Scale bars: $1 \mathrm{~mm}$. Photos: Frank Tillack (left) and Jakob Hallermann (right).

A. munoai, A. nigricauda, A. schmidti, and A. talisiae (countershading pattern), and from $A$. prunicolor (venter with a checkerboard pattern). By presenting a modal number of 14 midbody ventral segments, Amphisbaena slateri differs from A. hogei, A. manni, A. munoai, A. nigricauda, A. prunicolor, and A. schmidti (16), A. albocingulata (18), and $A$. darwinii (20). While all known specimens of $A$. slateri have four precloacal pores, most specimens of $A$. manni have six pores - females of $A$. nigricauda and $A$. prunicolor lack pores, but this trait is unknown in $A$. slateri, since no specimen was sexed. Postmental is distinctly longer than wide in A. slateri, while it is almost long as wide in A. darwinii, A. mensae, A. munoai, $A$. nigricauda, $A$. prunicolor, and $A$. talisiae. Parietals are enlarged in $A$. slateri, but not in $A$. manni and are irregular in $A$. darwinii. Finally, while the tail tip is rounded in A. slateri, it is conical in A. manni and has a slight lateral constriction in $A$. darwinii, A. hogei, and A. nigricauda.
Distribution and habitat. Amphisbaena slateri is known from southeastern Peru (Departamento Huánuco) to western Bolivia (Departamento La Paz) (Figure 5; Table 3). Locality records are in the Tropical and Subtropical Moist Broadleaf Forests biome (Ucayali Moist Forests, Southwest Amazon Moist Forests, and Bolivian Yungas ecoregions). The main soil types of the localities where the species is known are cambisol and regosol, with coarse (loamy sand or sandy loam) to medium textures (loam or silt loam).

\section{Discussion}

In this article, we update the diagnostic characters and the known distribution of Amphisbaena slateri based on an additional specimen housed at the Zoologisches $\mathrm{Mu}-$ seum, Universität Hamburg (ZMH R01282), and another from the University of Kansas (KUH 135171). These rep- 


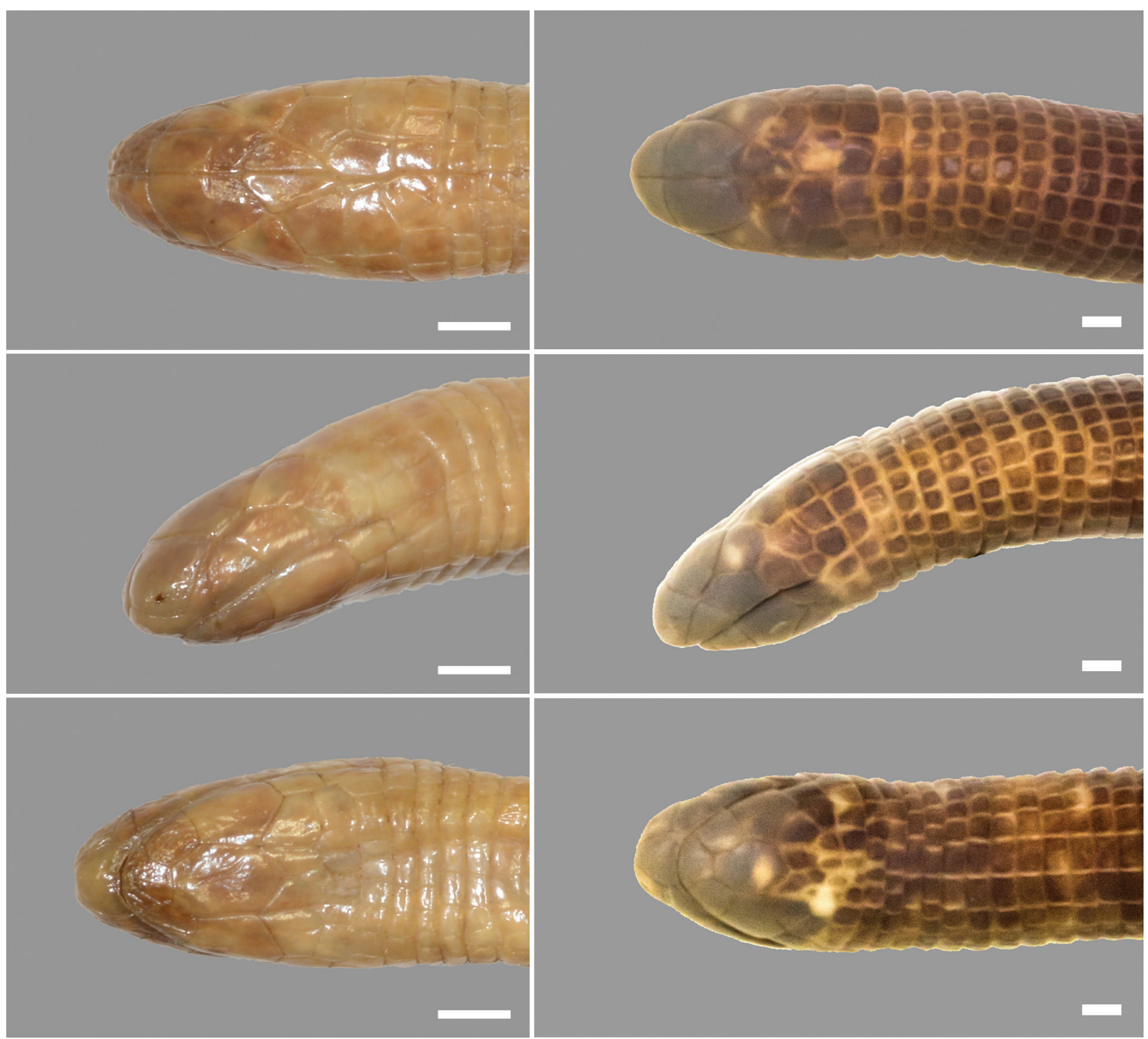

Figure 4. Amphisbaena slateri. Head in dorsal, lateral, and ventral view of ZMH R1282 (left), from Panguana Private Conservation Area, and KUH 135171 (right), from Misión Coribeni, Peru. Scale bars: 1 mm. Photos: Jakob Hallermann (left) and Luke J. Welton (right).

resent only the fourth and fifth specimens known for the species. ZMH R01282 was first identified by the late Carl Gans, who prepared a manuscript reporting his finding, which should have been published at the Mitteilungen aus dem Hamburgischen Zoologischen Museum und Institut (former name of this journal). The unpublished draft manuscript was recently found by $\mathrm{JH}$, and its reproduction (Suppl. material 1) was permitted by the Gans Collections and Charitable Fund Trustees (Eva Lynn Gans, e-mail to JH on 14 December 2017). Our study is the first to give detailed information on the place of origin and morphology (including photographs) of ZMH R01282, and, to the best of our knowledge, the first to report the existence of KUH 135171.

In the redescription of Amphisbaena slateri (Gans 1967) the three specimens examined were considered to have two rows of 'chin-segments', i.e., postgenials (Gans and Alexander 1962) - some authors call them 'median genials'(Vanzolini 1991, Pinna et al. 2010). The holotype of $A$. slateri clearly has two rows of postgenials, the first with two and the second with three scales (Figure 1). Specimen ZMB 10888 was said to have 3+6 postgenials (Gans 1967). It has, in fact, three scales between the malars (postgenials), but the following row of six scales should not be considered postgenials (sensu Gans and Alexander 1962) since they are posterior to the malars (Figure 3). One could argue this is a postmalar row, as the scales are between the last infralabial on each side. However, this row lies posterior to the angulus oris (mouth commissure), and should be counted as the first body annulus (Gans 1962b, 1964a, 1964b, $1964 c, 1966)$; the same is observed in BM 1946.8.31.82 and ZMH R01282 (Figures 1 and 4). Gans (1967) also cites four infralabials and $2+4$ postgenials for $\mathrm{ZMH}$ R05908, but this specimen has three infralabials (Gans's fourth infralabial is beyond the angulus oris) and three 
Table 2. Morphological characters useful for the identification of Peruvian and Bolivian Amphisbaenia $($ A. $=$ Amphisbaena; L. $=$ Leposternon). BA = body annuli; $\mathrm{CA}=$ caudal annuli; $\mathrm{AA}=$ autotomic annulus; $\mathrm{HS}=$ head shape: $\mathrm{R}$ (round), $\mathrm{K}$ (keel), or $\mathrm{S}$ (shovel); TT = tail tip: R (round), LC (slightly laterally compressed), VK (vertical keel); DS = dorsal segments (modal value in parenthesis); $\mathrm{VS}=$ ventral segments (modal value in parenthesis); $\mathrm{EP}=$ enlarged parietals (larger than adjacent body segments); $\mathrm{SL}=$ supralabials; $\mathrm{IL}=$ infralabials; $\mathrm{PG}=$ postgenial rows; $\mathrm{PM}=$ postmalar row; $\mathrm{PP}=$ precloacal pores (modal value in parenthesis).

\begin{tabular}{|c|c|c|c|c|c|c|c|c|c|c|c|c|c|}
\hline Species & BA & $\mathbf{C A}$ & AA & HS & TT & DS & VS & EP & SL & IL & PG & PM & PP \\
\hline A. alba & $198-248$ & $13-21$ & no & $\mathrm{R}$ & $\mathrm{R}$ & $30-42(36)$ & $35-46(38,40)$ & irregular & $3-4(4)$ & 3 & $1-2$ & yes & $4-12$ \\
\hline A. angustifrons & $190-218$ & $12-19$ & no & $\mathrm{R}$ & $\mathrm{LC}$ & 20-31 (24) & $21-36(28)$ & no & $3-4(4)$ & 3 & 2 & yes & $3-6(4)$ \\
\hline A. bolivica & $200-231$ & $18-26$ & $5-6$ & $\mathrm{R}$ & $\mathrm{R}$ & $27-38(30)$ & $26-36(28)$ & no & 4 & 3 & 2 & yes & $2-6(4,6)$ \\
\hline A. borelli & 239-261 & $17-19$ & $6-8$ & $\mathrm{R}$ & VK & $14-18(16)$ & $16-20(16)$ & no & 3 & 3 & 2 & no & 4 \\
\hline A. camura & $188-206$ & 14-19 & $4-6$ & $\mathrm{R}$ & $\mathrm{R}$ & 28-42 (39) & 29-46 (43) & no & 4 & 3 & 2 & yes & $2-6(4,6)$ \\
\hline A. cegei & 179-199 & $21-24$ & $6-8$ & $\mathrm{R}$ & $\mathrm{R}$ & $17-22(19)$ & $20-24(23)^{* *}$ & no & 3 & 3 & 2 & no & $0(+), 4($ Љ) \\
\hline A. fuliginosa & $180-220$ & $20-30$ & $5-7$ & $\mathrm{R}$ & $\mathrm{R}$ & $20-28$ & $18-28$ & no & 3 & $3-4$ & 2 & yes & $6-10$ \\
\hline A. heterozonata & $189-207$ & $13-18$ & $5-8$ & $\mathrm{R}$ & $\mathrm{LC}$ & $14-24(16)$ & $15-28(18)$ & irregular & 3 & 3 & $1-2$ & yes & $2-6(4)$ \\
\hline A. kingii & $214-244$ & $15-23$ & 7 & $\mathrm{~K}$ & $\mathrm{R}$ & $12-19(16)$ & 14-22(18) & no & 3 & 3 & 2 & no/yes & $0-4(0,4)$ \\
\hline A. occidentalis & $262-275$ & $17-20$ & no & $\mathrm{R}$ & $\mathrm{R}$ & $16-20(18)$ & $24-28(26)$ & no & 3 & 3 & $2-3$ & yes & 4 \\
\hline A. pericensis & 196-218 & $16-19$ & $6-8$ & $\mathrm{R}$ & $\mathrm{LC}$ & $12-16(14)$ & $16-20(18)$ & yes & 3 & 3 & 2 & no & $4-6(4)$ \\
\hline A. polygrammica & 270 & 22 & $?$ & $\mathrm{R}$ & $?$ & 18 & 26 & no & 3 & 3 & 1 & yes & 4 \\
\hline A. silvestrii & $173-190$ & $20-23$ & $4-7$ & $\mathrm{R}$ & $\mathrm{R}$ & $10-12(10)$ & $10-14(10)$ & yes & 3 & 3 & 2 & yes & 2 \\
\hline A. slateri & $176-213$ & $20-24$ & $7-10$ & $\mathrm{R}$ & $\mathrm{R}$ & $10-14(10,12)$ & $14-16(14)$ & yes & 3 & 3 & $1-2$ & no/yes & 4 \\
\hline A. steindachneri & $255-266$ & $17-19$ & 7 & $\mathrm{R}$ & $\mathrm{VK}$ & $12-16(14)$ & $12-16(14)$ & no & 3 & 3 & $1-2$ & no & 4 \\
\hline A. townsendi & $261-279$ & $22-26$ & $7-9$ & $\mathrm{R}$ & $\mathrm{R}$ & $16-18(18)$ & $24-28(26)$ & no & 3 & 3 & $2-3$ & yes & 4 \\
\hline L. microcephalum & *192-229 & $8-14$ & no & $\mathrm{S}$ & $\mathrm{R}$ & $17-31(21)$ & $17-31(22)$ & yes & 2 & 2 & 0 & yes & 0 \\
\hline
\end{tabular}

* number of post-pectoral ventral annuli.

** Ricardo Montero, pers. comm.

Table 3. Voucher, geographical coordinates, elevation, ecoregion (Dinerstein et al. 2017), and soil type (IUSS Working Group WRB 2015) of the collection localities of known specimens of Amphisbaena slateri. UMF: Ucayali Moist Forests; SAMF: Southwest Amazon Moist Forests; BY: Bolivian Yungas.

\begin{tabular}{|c|c|c|c|c|c|c|c|c|}
\hline Voucher & Country & Department & Locality & Latitude & Longitude & Elevation & Ecoregion & Soil type \\
\hline ZMH R1282 & Peru & Huánuco & Panguana Private Conservation Area & $-09.616^{\circ}$ & $-74.933^{\circ}$ & $260 \mathrm{~m}$ & UMF & Cambisol \\
\hline KUH 135171 & Peru & Cuzco & Misión Coribeni & $-12.600^{\circ}$ & $-72.800^{\circ}$ & $900 \mathrm{~m}$ & SAMF & Regosol \\
\hline BM 1946.8.31.82 & Peru & Puno & Carabaya, San Gaban river valley & $-13.437^{\circ}$ & $-70.403^{\circ}$ & $600-900 \mathrm{~m}$ & SAMF & Regosol \\
\hline ZMH R5908 & Bolivia & $\mathrm{LaPaz}$ & San Antonio & $-14.566^{\circ}$ & $-68.383^{\circ}$ & $1700 \mathrm{~m}$ & BY & Cambisol \\
\hline ZMB 10888 & Bolivia & $\mathrm{LaPaz}$ & Pelechuco & $-14.820^{\circ}$ & $-69.071^{\circ}$ & $3600 \mathrm{~m}$ & BY & Regosol \\
\hline
\end{tabular}

$\mathrm{H}=$ Holotype.

postgenials, followed by a row of six scales (the first body annulus), the outermost on each side larger than the rest (Figure 3). KUH 135171, however, has a postmalar row with seven scales (Figure 4). This variation regarding the postmalar row is not a common feature. It was also described for $A$. metallurga, from southeastern Brazil, and is linked with a polymorphism in the shape of the malars (Costa et al. 2015). The only specimen of A. slateri with a postmalar row (KUH 135171) has small malars that do not touch the third infralabials, contrary to the other four specimens.

In the 'Key to the American Amphisbaenia'(Gans and Mathers 1977), A. slateri is considered to have a postmalar row (step 40), which usually is not the case, as commented above. If the option 'without postmalar row' is chosen at step 40, the reader would follow to step $41 \mathrm{~b}$ ('four or more precloacal pores'), step 45a ('postmental shield markedly longer and of larger area than mental'), and finally step 46, where both possible options refers to species with more body annuli than $A$. slateri (A. xera with $225-234$ and $A$. carvalhoi with 231-245 body annuli). The key is certainly outdated, and its use should be avoided.
Amphisbaena slateri can be distinguished from most Bolivian and Peruvian amphisbaenians by the number of body and caudal annuli, segments, and precloacal pores, and the size of parietals. The only exception is $\mathrm{A}$. pericensis, from which it differs by the shape of the caudal tip, the relative size of the postmental scale, and color pattern. Ten Neotropical species (A. albocingulata, $A$. darwinii, A. hogei, A. manni, A. mensae, A. munoai, A. nigricauda, A. prunicolor, A. schmidti, and A. talisiae), from Argentina, Brazil, Hispaniola, Paraguay, and Puerto Rico (Gans 2005), share many morphological similarities with $A$. slateri. The phylogenetic relationships of most of them - A. slateri included - is not known (Dal Vechio et al. 2016), but it would be of no surprise if later it is found that such similarities are due to convergent evolution, as had been recently discovered for some taxonomically important morphological characters like the head shape (Kearney and Stuart 2004, Mott and Vieites 2009).

The identification of ZMH R01282 and KUH 135171 as Amphisbaena slateri greatly extends the known geographic range of the species. The new northernmost locality record, Panguana Private Conservation Area, is 650 

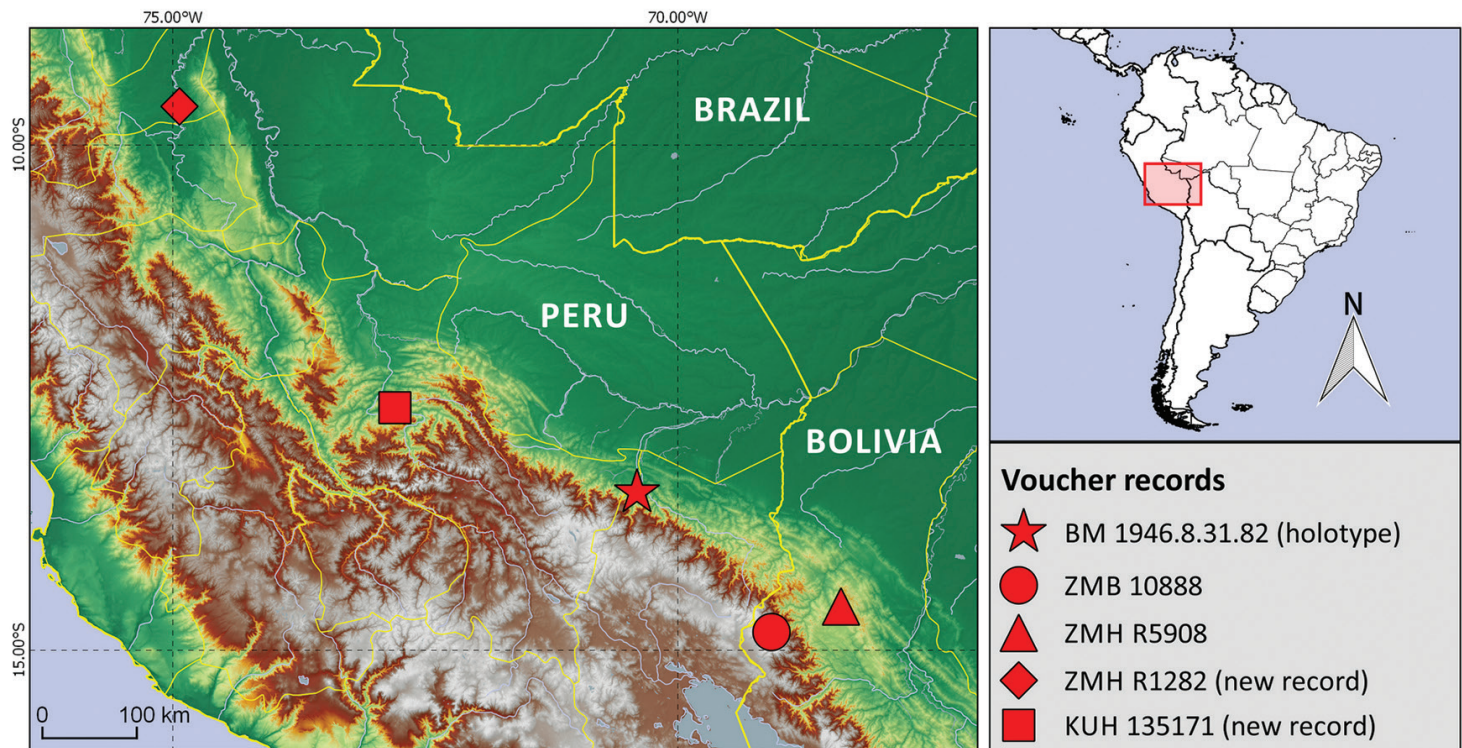

\section{Voucher records}

굴 BM 1946.8.31.82 (holotype)

ZMB 10888

$\triangle$ ZMH R5908

$\checkmark$ ZMH R1282 (new record) KUH 135171 (new record)

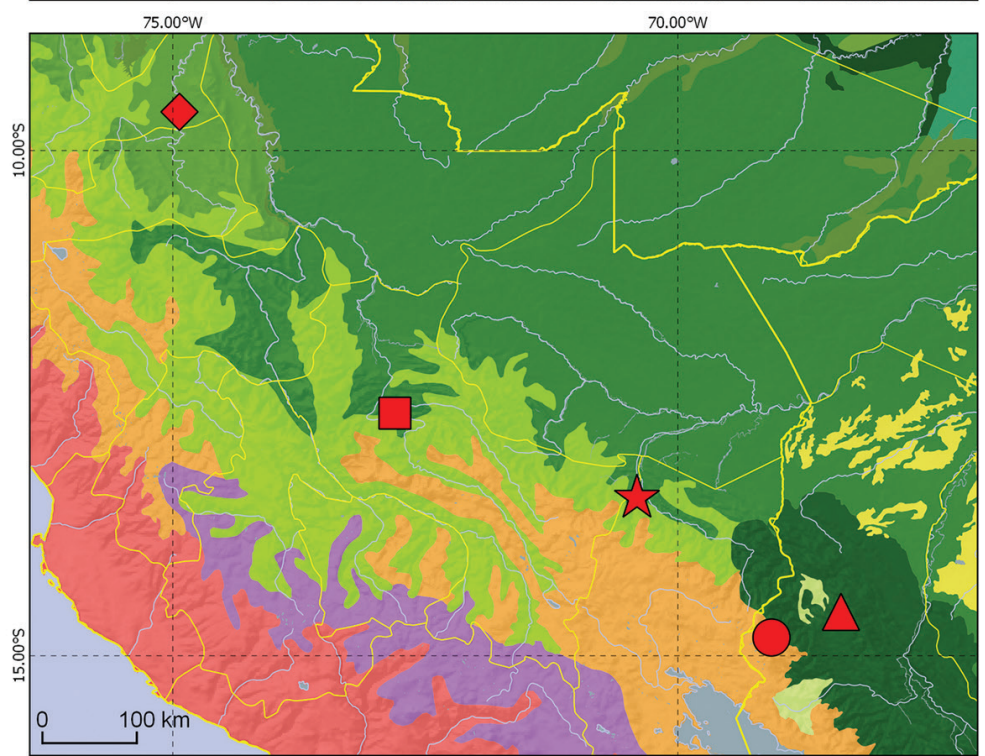

Political boundaries

Water

\section{Elevation (meters)}

$\square 100$

$\square 500$

$\square 1000$

$\square 1500$

$\square 2000$

$\square 2500$

$\square 3000$

$\square 3500$

$\square 4000$

$\square 4500$

$\square 5000+$

\section{Ecoregions}

Beni savanna

Bolivian montane dry forests

Bolivian Yungas

Central Andean puna

Central Andean wet puna

Iquitos várzea

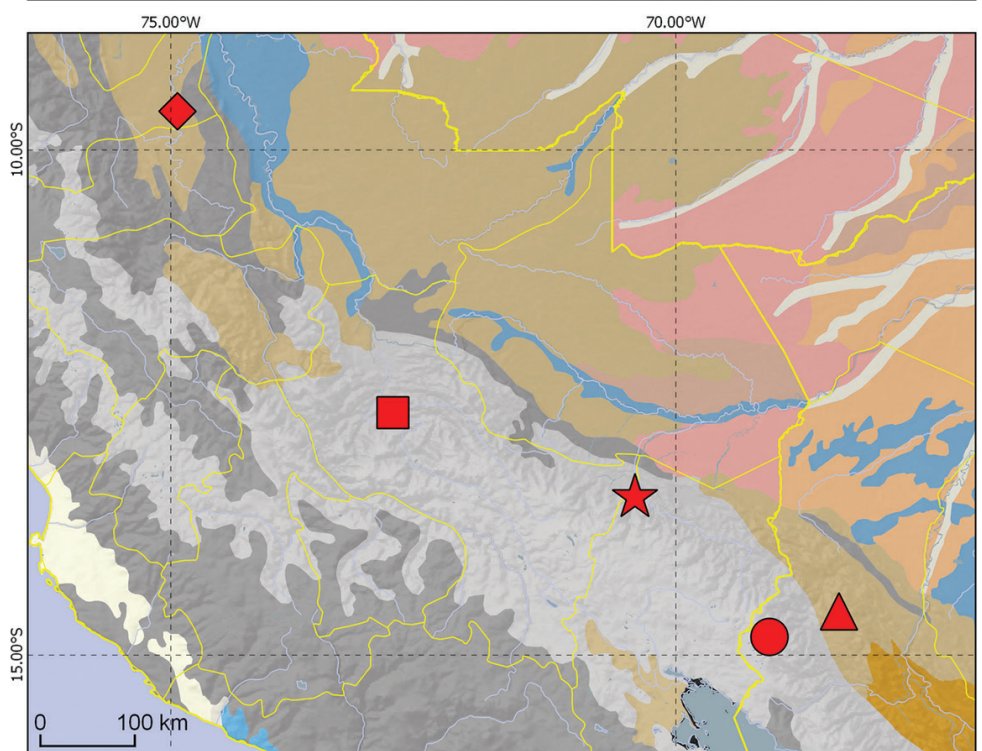

Juruá-Purus moist forests

Peruvian Yungas

Purus várzea

Purus-Madeira moist forests

- Sechura desert

- Southwest Amazon moist forests

- Ucayali moist forests

\section{Soil types}

- Acrisol

Arenosol

- Cambisol

Fluvisol

Ferralsol

Gleysol

Leptosol

Luvisol

Lixisol

Regosol

Solonchack

Figure 5. Known locality records for Amphisbaena slateri on a background of elevation gradient (top map), ecoregions (middle map), and soil type (bottom map). 
$\mathrm{km}$ northwest of the type locality in the San Gaban river valley, and 400 northwest of Misión Coribeni, the closest site where the species is known to occur. Panguana is located at $260 \mathrm{~m}$ above sea level (m a.s.1.), the lowest elevation record for the species, while Misión Coribeni is at about $900 \mathrm{~m}$ a.s.l. Unfortunately, there is no precise elevation data for the holotype and for the two Bolivian specimens, which came from areas with rugged relief. But even if considering only the elevation of the valleys around of each locality, $A$. slateri inhabits areas between 260 and $3600 \mathrm{~m}$ a.s.1, probably the greatest elevation gradient among amphisbaenians (Gans 2005).

Amphisbaena slateri is an inhabitant of the Tropical and Subtropical Moist Broadleaf Forests (TSMBF) at the Andean foothills. The record of Pelechuco - not Pelecnes as stated in the specimen label and in Gans (1967) (Dirksen and Riva 1999) - could be considered an ecotone, between the TSMBF and the Montane Grasslands and Shrublands Biome (Central Andean Wet Puna ecoregion). However, given that the Wet Puna is characterized as a mountain grassland region (World Wildlife Fund 2018) and that $A$. slateri seems to be a forest inhabitant (Schlüter et al. 2004), it would be more probable that the specimen from Pelechuco was collected in the valleys of the Bolivian Yungas ecoregion. Cambisols and regosols, the two soil types from the localities where Amphisbaena slateri is recorded, are common in the region and mainly formed by the weathering of the rocks of the Andes (Gardi et al. 2014). Their texture along the known range of the species varies from a loamy sand (coarse texture) to silt loam (medium texture) (Nachtergaele et al. 2009), characteristics apparently suitable for any amphisbaenian, especially one with a generalized head shape like $A$. slateri (Gans 1968).

The morphological variation observed between the two Bolivian specimens (south) and the holotype (north), led to the suggestion that the 'south' and 'north' specimens could represent distinct populations (Gans 1967) or even 'races' (Gans 2005). Considering the sample now available, we note that the Peruvian specimens show more body annuli (202-213) and less midbody ventral segments (14) than the Bolivian ones $(176-183 ; 16)$. Available data (Table 3 ) indicate the Bolivian specimens were collected at higher elevations, in areas probably of lower environmental temperatures. A possible influence of environmental temperature on somite formation (and hence in the number of body annuli in worm lizards and ventral plates in snakes) was detected by some authors (Vanzolini 1955, 1968, Hoge et al. 1977, Osgood 1978), but has recently been questioned (Arnold and Peterson 2002, Grazziotin et al. 2006). In spite of this, clinal variation is known for some worm lizard species (Vanzolini 1968, 2002, Saiff 1970, Montero 2016), but the availability of only five museum specimens of $A$. slateri hinders any adequate inference on whether the differences observed for this taxon is a sampling artifact, an indicative of clinal variation, or is even linked to undocumented taxonomic diversity.

Amphisbaena slateri is a poorly studied species and the two specimens described here, despite being collect- ed decades ago, remained forgotten on museum shelves. This is not an uncommon phenomenon and reinforces the importance of continuous care and study of specimens deposited in natural history collections (Fontaine et al. 2012, Koch 2014). It is possible that additional specimens of $A$. slateri remain unidentified in other collections. We hope the information provided in this article helps curators, collection managers, and field biologists in the identification of Bolivian and Peruvian amphisbaenians, facilitating the discovery of additional records of $A$. slater $i$ and other species in the future.

\section{Acknowledgments}

We thank Alan Resetar (FMNH), Frank Tillack (ZMB), and Patrick Campbell (BM) for sending photographs of specimens under their care; Jackson Roberts (LSUMZ) for data about specimens under his care; Diego J. Santana and Thomaz Sinani (UFMS), Paulo Manzani and Karina Rebelo (ZUEC), and Felipe F. Curcio (UFMT) for the loan of specimens under their care; To Ricardo Montero for information on A. cegei; Evan Gans and Gans Collections and Charitable Fund Trustees for authorizing the reproduction of Carl Gans's unpublished manuscript. Renata Perez and an anonymous reviewer provided valuable comments on the submitted manuscript. HCC was supported by a D.Sc. scholarship from Coordenação de Aperfeiçoamento de Pessoal de Nível Superior (CAPES).

\section{References}

Arnold SJ, Peterson CR (2002) A Model for Optimal Reaction Norms: The Case of the Pregnant Garter Snake and Her Temperature-Sensitive Embryos. The American Naturalist 160: 306-316. https://doi. org/10.1086/341522

Boulenger GA (1907) Descriptions of new lizards in the British Museum. Annals and Magazine of Natural History 19: 486-489. https:// doi.org/10.1080/00222930709487278

Colli GR, Fenker J, Tedeschi LG, Barreto-Lima AF, Mott T, Ribeiro SLB (2016) In the depths of obscurity: Knowledge gaps and extinction risk of Brazilian worm lizards (Squamata, Amphisbaenidae). Biological Conservation 204: 51-62. https://doi.org/10.1016/j.biocon.2016.07.033

Costa HC, Resende FC, Teixeira Jr M, Dal Vechio F, Clemente CA (2015) A new Amphisbaena (Squamata: Amphisbaenidae) from southern Espinhaço Range, southeastern Brazil. Anais da Academia Brasileira de Ciências 87: 891-901. https://doi.org/10.1590/00013765201520140088

Costa HC, Señaris JC, Rojas-Runjaic FJM, Zaher H, Garcia PCA (2018) Redescription of the rare South American worm lizard Amphisbaena rozei (Squamata: Amphisbaenidae). Amphibia-Reptilia 39: 21-30. https://doi.org/10.1163/15685381-00003136

Dal Vechio F, Teixeira Jr M, Sena M, Argôlo A, Garcia C, Rodrigues MT (2016) Taxonomic Status and the Phylogenetic Placement of Amphisbaena leucocephala Peters, 1878 (Squamata, Amphisbaenidae). South American Journal of Herpetology 11: 157-175. https:// doi.org/10.2994/SAJH-D-16-00027.1 
Dinerstein E, Olson D, Joshi A, Vynne C, Burgess ND, Wikramanayake E, Hahn N, Palminteri S, Hedao P, Noss R, Hansen M, Locke H, Ellis EC, Jones B, Barber CV, Hayes R, Kormos C, Martin V, Crist E, Sechrest W, Price L, Baillie JEM, Weeden D, Suckling K, Davis C, Sizer N, Moore R, Thau D, Birch T, Potapov P, Turubanova S, Tyukavina A, de Souza N, Pintea L, Brito JC, Llewellyn OA, Miller AG, Patzelt A, Ghazanfar SA, Timberlake J, Klöser H, Shennan-Farpón Y, Kindt R, Lillesø J-PB, van Breugel P, Graudal L, Voge M, Al-Shammari KF, Saleem M (2017) An Ecoregion-Based Approach to Protecting Half the Terrestrial Realm. BioScience 67: 534-545. https://doi.org/10.1093/biosci/bix014

Dirksen L, Riva I de la (1999) The lizards and amphisbaenians of Bolivia (Reptilia, Squamata): Checklist localities and bibliography. Graellsia 55: 199-215. https://doi.org/10.3989/graellsia.1999.v55.i0.329

Evans JW (1903) Expedition to Caupolican Bolivia, 1901-1902. The Geographical Journal 22: 601-642. https://doi.org/10.2307/1775091

Fontaine B, Perrard A, Bouchet P (2012) 21 years of shelf life between discovery and description of new species. Current Biology 22: R943-R944. https://doi.org/10.1016/j.cub.2012.10.029

Gans C (1961) Notes on Amphisbaenids (Amphisbaenia: Reptilia). 2. Amphisbaena occidentalis Cope from the Coastal Plain of Northern Peru. Postilla 56: 1-17.

Gans C (1962a) Notes on Amphisbaenids (Amphisbaenia, Reptilia). 5: A Redefinition and a Bibliography of Amphisbaena alba Linné. American Museum Novitates 2105: 1-32. https://doi. org/10.2307/1439492

Gans C (1962b) Redefinition and description of the Brasilian reptiles Amphisbaena silvestrii Boulenger and A. neglecta Dunn and Piatt. Copeia 1962: 164-170.

Gans C (1963) Notes on Amphisbaenids (Amphisbaenia: Reptilia). 10. Redescription and redefinition of Amphisbaena pericensis Noble from the mountains of northwestern Peru. Breviora 189: 1-15.

Gans C (1964a) Amphisbaena schmidti, a third species of the genus from Puerto Rico (Amphisbaenia: Reptilia). Breviora 198: 1-11.

Gans C (1964b) New Records of Amphisbaena silvestrii Boulenger, and the Description of a New Two-Pored Species from the Northern Chaco. Copeia 1964: 553-561. https://doi.org/10.2307/1441523

Gans C (1964c) Redescription of Amphisbaena dubia Müller (Amphisbaenia: Reptilia). Breviora 205: 1-11.

Gans C (1964d) The South American species of Amphisbaena with a vertically keeled tail (Reptilia, Amphisbaenidae). Notes on amphisbaenids 15. Senckenbergiana Biologica 45: 387-416.

Gans C (1966) Studies on Amphisbaenids (Amphisbaenia, Reptilia) 3. The small species from southern South America commonly identified as Amphisbaena darwini. Bulletin of the American Museum of Natural History 134: 185-260.

Gans C (1967) Redescription of Amphisbaena slateri Boulenger, with comments on its range extension into Bolivia. Herpetologica 23: 223-227.

Gans C (1968) Relative success of divergent pathways in Amphisbaenian specialization. The American Naturalist 102: 345-362. https:// doi.org/10.1086/282548

Gans C (2005) Checklist and bibliography of the Amphisbaenia of the World. Bulletin of the American Museum of Natural History 289: 1-130. https://doi.org/10.1206/0003-0090(2005)289<0001:CABOTA $>2.0 . \mathrm{CO} ; 2$

Gans C, Alexander AA (1962) Studies on the amphisbaenids (Amphisbaenia; Reptilia). 2. On the amphisbaenids of the Antilles. Bulletin of the Museum of Comparative Zoology 128: 65-158.
Gans C, Amdur MA (1966) Redescription of Amphisbaena vermicularis Wagler, with comments on its range and synonymy (Amphisbaenia: Reptilia). Proceedings of the California Academy of Sciences 66: 69-90.

Gans C, Diefenbach COC (1972) Description and Geographical Variation of the South American Amphisbaena angustifrons: the Southernmost Amphisbaenian in the World (Reptilia, Amphisbaenia). American Museum Novitates 2494: 1-20.

Gans C, Mathers S (1977) Amphisbaena medemi, An Interesting New Species from Colombia (Amphisbaenia, Reptilia), with a Key to the Amphisbaenians of the Americas. Fieldiana (Zoology) 72: 21-46.

Gardi C, Angelini M, Barceló S, Comerma J, Cruz Gaistardo C, Encina Rojas A, Jones A, Krasilnikov P, Mendonça Santos Brefin ML, Montanarella L, Muñiz Ugarte O, Schad P, Vara Rodríguez MI, Vargas R (2014) Atlas de suelos de América Latina y el Caribe. Oficina de Publicaciones de la Unión Europea, Luxembourg, 176 pp.

Grazziotin FG, Monzel M, Echeverrigaray S, Bonatto SL (2006) Phylogeography of the Bothrops jararaca complex (Serpentes: Viperidae): past fragmentation and island colonization in the Brazilian Atlantic Forest. Molecular Ecology 15: 3969-3982. https://doi. org/10.1111/j.1365-294X.2006.03057.x

Hoge AR, Belluomini HE, Fernandes W (1977) Variação do número de placas ventrais de Bothrops jararaca em função dos climas [Viperidae, Crotalinae]. Memórias do Instituto Butantan 40/41: 11-17.

IUSS Working Group WRB (2015) 106 World Soil Resources Reports World Reference Base for Soil Resources 2014, update 2015 International soil classification system for naming soils and creating legends for soil maps. Food and Agriculture Organization of the United Nations, Rome, 192 pp.

Kearney M, Stuart BL (2004) Repeated evolution of limblessness and digging heads in worm lizards revealed by DNA from old bones. Proceedings. Biological sciences / The Royal Society 271: 1677-1683. https://doi.org/10.1098/rspb.2004.2771

Koch A (2014) Correct voucher specimen data reduce "shelf life" of undescribed species. Herpetozoa 26: 204-206.

Montero R (1996) Amphisbaena bolivica Mertens 1929, nueva combinación (Squamata: Amphisbaenia). Cuadernos de Herpetologia 9: 75-84.

Montero R (2001) Amphisbaena cegei. Catalogue of American Amphibians and Reptiles 726: 1-3.

Montero R (2016) On the Validity of Several Argentinian Species of Amphisbaena (Squamata, Amphisbaenidae). Journal of Herpetology 50: 642-653. https://doi.org/10.1670/15-048

Mott T, Vieites DR (2009) Molecular phylogenetics reveals extreme morphological homoplasy in Brazilian worm lizards challenging current taxonomy. Molecular Phylogenetics and Evolution 51: 190200. https://doi.org/10.1016/j.ympev.2009.01.014

Nachtergaele F, van Velthuizen H, Verelst L (2009) Harmonized World Soil Database. Version 1.1. FAO and IIASA, Rome, Laxenburg.

Osgood DW (1978) Effects of Temperature on the Development of Meristic Characters in Natrix fasciata. Copeia 1978: 33-47. https://doi. org/10.2307/1443819

Perez R, Ribeiro S, Borges-Martins M (2012) Reappraisal of the taxonomic status of Amphisbaena prunicolor (Cope 1885) and Amphisbaena albocingulata Boettger 1885 (Amphisbaenia: Amphisbaenidae). Zootaxa 3550: 1-25.

Pinna PH, Mendonça AF, Bocchiglieri A, Fernandes DS (2010) A new two-pored Amphisbaena Linnaeus from the endangered Brazilian Cerrado biome (Squamata: Amphisbaenidae). Zootaxa 2569: 44-54. 
Ribeiro S, Santos-Jr AP, Zaher H (2015) A new species of Leposternon Wagler, 1824 (Squamata, Amphisbaenia) from northeastern Argentina. Zootaxa 4034: 309-324. https://doi.org/10.11646/zootaxa.4034.2.4

Saiff EI (1970) Geographical Variation in the genus Zygaspis (Amphisbaenia: Reptilia). Herpetologica 26: 86-119.

Schlüter A, Icochea J, Perez JM (2004) Amphibians and reptiles of the lower Río Llullapichis, Amazonian Peru: updated species list with ecological and biogeographical notes. Salamandra 40: 141-160.

Stephens L, Traylor MA (1983) Ornithological Gazetteer of Peru. Museum of Comparative Zoology, Cambridge, $271 \mathrm{pp}$.

United States Government (2001) Yuyapichi, Peru. Edition 2-NIMA, Series J632, Sheet 1951. National Imagery and Mapping Agency, Bethesda, $1 \mathrm{pp}$.

Vanzolini PE (1955) Contribuições ao conhecimento dos lagartos brasileiros da família Amphisbaenidae Gray, 1825. Distribuição geográfica e biometria de Amphisbaena alba L. Arquivos do Museu Nacional 42: 683-706.

Vanzolini PE (1968) Environmental temperature and number of body annuli in Amphisbaena alba: notes on a cline (Sauria, Amphisbaenidae). Papéis Avulsos de Zoologia 21: 231-241.

Vanzolini PE (1991) Two new small species of Amphisbaena from the fossil dune field of the middle Rio São Francisco, State of Bahia, Brasil (Reptilia, Amphisbaenia). Papéis Avulsos de Zoologia 37: 259-276.

Vanzolini PE (1999) On Anops (Reptilia: Amphisbaenia: Amphisbaenidae. Papéis Avulsos de Zoologia 41: 1-37.

Vanzolini PE (2002) A second note on the geographical differentiation of Amphisbaena fuliginosa L., 1758 (Squamata, Amphisbaenidae), with a consideration of the forest refuge model of speciation. Anais da Academia Brasileira de Ciências 74: 609-648. https://doi. org/10.1590/S0001-37652002000400006

Werner F (1901) Reptilien un Batrachier aus Peru und Bolivien. Abhandlungen und Berichte des Königl. Zoologischen und Anthropologisch-Etnographischen Museums zu Dresden 9: 1-14.

Werner F (1910) Über neue oder seltene Reptilien des Naturhistorischen Museums in Hamburg. II. Eidechsene. Jahrbuch der Hamburgischen Wissenschaftlichen Anstalten 27: 1-48.

World Wildlife Fund (2018) Western South America: Peru and Bolivia. Ecoregions. Available from: https:/www.worldwildlife.org/ecoregions/nt1003. [April 2, 2018]

\section{Appendix 1}

Specimens examined, not cited by Costa et al. (2018). UFMT: Universidade Federal do Mato Grosso, Brazil; ZUEC: Universidade Estadual de Campinas, Brazil; ZUFMS: Universidade Federal do Mato Grosso do Sul, Brazil. Locality names indicated as 'COUNTRY: STATE: Municipality, Specific Locality'.

Amphisbaena camura. BRAZIL: MATO GROSSO DO SuL: unknown locality (ZUFMS 828, 829); Anastácio, Estância Crioula (ZUFMS 088); Aquidauana (ZUFMS 080, 328, 1243), Vila Bancária (ZUFMS 070), Guanandy (ZUFMS 093). Amphisbaena hogei. BRAZIL: São PAUlo: Guará, Eixo-Retiro (ZUEC 3310, 3311, 3313). Amphisbaena kiriri. BRAZIL: BAHIA: Campo Formoso (MFCH 3939 [holotype], UFMG 3080, 3081 [paratypes]). Amphisbaena leeseri. BRAZIL: Mato Grosso Do Sul: Três Lagoas, Fazenda Barra da Moeda (ZUEC 3501, 3747, 3748). Amphisbaena nigricauda. BRAZIL: EsPírito SANTo: Vitória, Praia de Camburi (UFMT 9157, 9158, 9167, 9169, 9170).

\section{Supplementary material 1}

Unpublished typed manuscript by Carl Gans, written in 1980 reporting the discovery of ZMH R1282. This manuscript should have been published at the Mitteilungen aus dem Zoologischen Museum Hamburg (former name of Evolutionary Systematics) but was never submitted. Reproduced with the authorization of Gans Collections and Charitable Fund Trustees

Authors: Henrique C. Costa, Luke J. Welton, Jakob Hallermanne Data type: species information

Copyright notice: This dataset is made available under the Open Database License (http://opendatacommons.org/licenses/odbl/1.0/). The Open Database License (ODbL) is a license agreement intended to allow users to freely share, modify, and use this Dataset while maintaining this same freedom for others, provided that the original source and author(s) are credited.

Link: https://doi.org/10.3897/evolsyst.2.28059.suppl1 